\title{
The Implementation Of Context, Input, Process, And Product Evaluation Theory In Contextual Learning Of Indonesian History In Semedo Ancient Site, Semedo Village, Kedungbanteng Sub District, Tegal Regency, Central Java, Indonesia
}

\author{
Khamalida Fitriyaningsih, \\ State Vocational High School 1 Dukuhturi \\ Tegal, Indonesia \\ malidafitri@gmail.com
}

\author{
Syamsul Bakhri \\ Sociological Postgraduate Program of Universitas \\ Sebelas Maret, \\ Surakarta, Indonesia \\ s_bakhri@rocketmail.com
}

\begin{abstract}
Contextual learning focuses on involving the students actively to acquire their own understanding in the field.Contextual learning is an appropriate approach when applied to Indonesian History subject, because the students can understand better the material studied. The implementation of Indonesian History learning in the State Vocational High School 1 Dukuhturi Tegal had been based on contextual learning, particularly the material of life pattern in preliterate period by visiting Semedo Ancient Site. This qualitative research using case study aimed to find out the effectiveness of Indonesian History learning in the State Vocational High School 1 Dukuhturi Tegal in Semedo Ancient Site. Data validation was carried out using data source triangulation. Technique of analyzing data used integrated data resulting from the observation on fossil finding place, interview with student, fossil inventor, ancient site organizer, and documentation from many sources to support information in Semedo Ancient Site. The theory employed was Daniel Stufflebeam's Evaluation theory including Context, Input, Process, and Product. The result of research showed that educators learned more enthusiastically Indonesian History, pre-literate human life pattern, characteristics of fossil deriving from middle pleistocene period, and can distinguish the type of life instruments in Mesolithic and Neolithic periods.
\end{abstract}

Keywords: Contextual learning, Semedo Ancient Site, Indonesian History

\section{INTRODUCTION}

Social Science subject, particularly Indonesian History, is known as the one with thick book and much material. Learning strategy emphasizing on theoretical aspect and abstraction makes Indonesian History labeled "recitation lesson". The conventional learning method the History teacher still uses makes learning circumstance uncomfortable and boring. As a result, the students can only understand the material at recitation level and has not captured the meaning obtained from learning to be applied in daily life.

Therefore, teacher should be able to deconstruct the image of Indonesian History subject by means of designing learning strategy teaching material not only at theoretical level but also practical level. Teacher should be able to create learning model leading the students to learn any subject matter more vigorously. In addition, teacher should be able to create a comfortable and joyful learning condition to make the students understand, interpret and connect the material learnt to the condition of surrounding environment and reflect on the life values acquired.

Indonesian history subject focuses on three time dimensions, the study of which stops not only in the past event but also in the relation between the past and the present events, and reflection on the past event thereby becoming the guideline in the future. Thus, history learning applying recitation aspect and oriented to the achievement of all materials taught without considering the interrelationship between the three time dimensions precisely is considered as inappropriate as it is considered as failed to produce active, creative, and innovative students, exploring their own knowledge 
actively, connecting the material studied to the surrounding environment creatively, and finding the pattern to be applied in the future life innovatively. The implication is that the students successfully recall and memorizes the material in short term only. Considering this, teacher should equip the students with an ability of connecting material studied to the context or Contextual Teaching Learning (CTL).

Nurhadi states that Contextual Teaching and Learning is the learning concept helping teacher to connect material taught to real world situation of students and encouraging the students to establish the relation between knowledge they have and its application in their life as family and society members. Through that concept, the learning outcome is expected to be more meaningful to the students [1]. Learning process runs naturally in the form of students' activities of working and experiencing, rather than the transfer of knowledge from teacher to students; learning strategy transcends the outcome.

\section{METHODS}

This research was conducted in SMK Negeri 1 Dukuhturi, Tegal, Central Java, Indonesia from January to March 2017. Data and information in this qualitative research with case study approach consisted of meaningful subjective experiences of students, teachers assuming Indonesian History subject, and Semedo museum organizer. This qualitative research with case study approach aimed to find out the effectiveness of Indonesian History learning in SMK Negeri 1 Dukuhturi Tegal in Semedo Ancient Site. Data validation was carried out using data source triangulation. Technique of analyzing data used integrated data of observation result in fossil finding place, interview with students, fossil finder, museum organizer and documentation from various sources to support information in Semedo Ancient Site. The theory employed was Daniel Stufflebeam's Context, Input, Process, and Product evaluation theory. Case study analysis started with following theoretical proposition and using pattern mating logic. Theoretical proposition was made to help focus the author's attention on data corresponding to theoretical proposition and ignore other, to help organize all case studies, and to determine alternative explanation to be tested. Meanwhile, the pattern mating logic was used to compare the pattern empirically (description of case existing in the field) with the author's predicted pattern or with some alternative predictions [2].

\section{RESULT AND DISCUSSION}

CIPP evaluation theory developed by Daniel Stufflebeam standing for context evaluation, input evaluation, process evaluation, and product evaluation. Those four things are the component of evaluation.

CIPP model is a decision-orientation evaluation approach. It aims to help the administrators (headmaster and teacher) make decision. Stufflebeam in Eko Putro Widoyoko states that, "the CIPP approach is based on the view that the most important purpose of evaluation is not to prove but improve." Stufflebeam offers the concept considering that the important objective of evaluation is not to authenticate but to improve [3].

Components and dimensions of CIPP model including context, input, process, and product will be discussed below:

\section{A. Context Evaluation}

Stufflebeam in Hamid Hasan mentions that the objective of context evaluation is mainly to find out strength and weakness of evaluant. Knowing this strength and weakness, evaluator will be able to give the necessary improvement direction [4].

Arikunto and Safrudin explain that context evaluation is the attempt of representing and detailing the unfulfilled need environment, population and sample served, and project objective [5]. In this case, Suharsimi give an example of evaluation on school child's supplemental food program (PMTAS) in posing the evaluation question as follows: What needs have not been fulfilled yet by the program, i.e. the type of food and students not receiving; what objective of development has not been achieved by program, i.e. the improvement of students' health and achievement due to supplement food; what objective of development can help develop society, i.e. parents' awareness of giving nutritious food to their children; what objective are most easily achieved, i.e. evenly food distribution, appropriate food supply.

\section{B. Input Evaluation}

The second stage of CIPP model is input evaluation. Input evaluation, according to Widoyoko, helps decision making, determines the existing sources, alternative taken, plan and strategy to achieve objective, and work procedure to achieve it [3]. Input evaluation component includes human resource; supporting infrastructure, fund or budget, and various procedures and rule necessary. In this case, the questions can be proposed in this input evaluation are: does the food given to students affect clearly the students' development? How many students do receive food supplement gladly? How is the students' reaction to lesson after receiving supplement food? And how far is the increase of students' value after receiving supplement food. 
Stufflebeam in Arikunto and Safrudin says that the question regarding input leads to problem solving encouraging the implementation of corresponding program [5].

\section{Evaluation Process}

Worthen \& Sanders in Widoyoko explains that process evaluation emphasizes on three objectives: "1) do detect or predict in procedural design or its implementation during implementation stage, 2) to provide information for programmed decision, and 3) to maintain a record of the procedure as it occurs" [3].

Process evaluation is used to detect or to predict procedure design or implementation design during implementation stage, to provide information for program decision and as procedure recording or archive occurring. Process evaluation includes collecting data of assessment specified and applied in program implementation practice. Basically, process evaluation is intended to find out the extent to which the plan has been applied and what component needs improvement. Meanwhile, according to Suharsimi Arikunto, process evaluation in CIPP model points to "what" activity is conducted in the program, "who" is designated to be the one responsible for the program, "when" the activity will be complete. In CIPP model, process evaluation focuses on the extent to which an activity conducted in the program has been implemented as planned. Stufflebeam proposes questions for process as follows: Is the program implementation consistent with the schedule; Will the staffs involved in program implementation be able to cope with the activity during the program and when it is continued? Are infrastructures provided used maximally? What are constraints encountered during program implementation and when it is continued?

\section{Product Evaluation}

Sax in Widyoko defines product evaluation as "to allow to project director (or teacher) to make decision of program "[6]. Process evaluation is expected to help the project leader or teacher make decision regarding the continuation, end, or program modification. Meanwhile, Tayibnapis in Widyoko explains that product evaluation is intended to help make further decision, regarding either the output to be achieved or what to be done after the program proceeds [3].

From the argument above, it can be concluded that product evaluation is an assessment conducted to see the achievement/the success of a program in achievement previously specified objectives. At this evaluation stage, an evaluator can determine or recommend the evaluant about whether a program can be continued, developed/modified, or terminated. At this evaluation stage, the following evaluation questions are posed: have the specified objective achieved? What are questions likely misleading related to the detail process with the achievement of objective? In what case the students' need have been met in the process of administering supplement food (e.g. food variation, food amount, and feeding time appropriateness); What effect does the students obtained in relatively long time in this presence of supplement food?.

Semedo Ancient Site of Tegal Regency is located in Semedo Village of Kedung Banteng Sub District, about $20 \mathrm{~km}$ to the north of Slawi City of Tegal Regency of Central Java Province. The finding of Semedo ancient site started with Mr Dakri's finding of fossil scattered haphazardly on the land without exploration process in 2003.

In 2005, Semedo Ancient Site appeared in public scientific stage with Gerbang Mataram NGO's help exposing vertebrate fossils in Semedo forest area; then Gerbang Mataram NGO exposes the finding of vertebrate fossils from Semedo forest in printed and electronic media.

Furthermore, Education and Culture Service of Tegal Regency reports the finding to Tegal Regent, and ask Yogyakarta Archaeology Center to conduct some research. Recalling that the finding is very important and can give a description on fauna evolution and ancient environment in Pleistocene time, particularly in Tegal Regency, Yogyakarta Archaeology Center observed the finding location immediately to identify the finding and the management of site in the future.

Excavation process of fossil exploration process was conducted continuously to be inventoried and secured in Mr Dakri (the finder of fossil)'s house. The fossils found in Semedo Ancient Site, according to Qudsiyati Ika Muriana [6], consist of 3 fossil categories: firstly, Paleontology. In this category, the types of fauna identified include Elephantidae (ancient elephant), Bovidae (buffalo, cow, wild ox), Cervidae (a kind of deer), Rhinoceros sp (rhinoceros), Suidae (pig), Hippopotamus sp, Canidae, Felidae, Hyaenidae, Chelonidae (turtle), Crocodilidae (crocodile), and Lamnidae (shark), and invertebrate including phylum Ceolenterata, Echinodermata, and mollusks. Secondly, archaeology category. In this category, lithic artifact collection found in Semedo Site is massive and nonmassive stone tools. The massive stone tools consist of chopping, copper, hand axe, polyhedral, core, and percutor, while non-massive one consists of splinter tool, splinter, carpentry tool, drill, non-intentional splinter. These gravel coral materials are found only in Semedo Site and the main characteristics of it, as they have never been found in other Paleolithic sites. And thirdly, paleoanthropology category in which Homo erectus's upper skull from Middle Pleistocene time (about 700,000 thousands years ago) has been found, but its original deposition location has not been found out. Considering the result of research conducted, it can be said that Semedo Site is a new Pleistocene Time that can show great potency for the understanding on environment, 
fauna, and ancient human evolutions in Pleistocene Time in Java.

Historical learning should be holistic and contextual in this era. It because it plays a strategic role in reinforcing the nationality spirit and love to homeland and generates the awareness of continuity corresponding to the object of historical science study. In addition, historical education is required to pay attention to thinking skill development in its learning process. Through historical education, the students are invited to study the interrelationship between the life they, society and their nation experience, so that they grow into a young generation with historical consciousness, get inspiration or good lesson from heroic stories and national tragedy, thereby finally encouraging the creation of rational-critical-empirical thinking pattern, and historical learning that develop the attitude of appreciating humanity values. It is in line with what suggested in the formulation of historical education objective in Indonesia, stating that historical education aims to socialize to the students that there will be society change and development processes in time dimension, and to build perspective and historical consciousness in finding, understanding, and explaining the nation's selfidentity in the past, the present, and the future amid the world transformation [7].

In line with the 2013 curriculum based on constructivism learning, Indonesian historical learning should applies the principles of constructivism learning, one of which is context learning model or contextual teaching learning. In the syllabus of Indonesian History subject in the first semester of $10^{\text {th }}$ grade, in Basic Competency 3.4, there are indicators of analysis based on Indonesian Initiative's cultural product typology, including the one existing in proximate environment with indicator 4.4 presenting the result of reasoning about society's life pattern in preliterate period in the form of writing.

CIPP theory includes: context, input, process, and product analysis. Meanwhile, analysis on Semedo ancient site learning includes: historical learning in SMK Negeri 1 Dukuhturi has applied contextual learning model, in which all of the $10^{\text {th }}$ graders visit Semedo Ancient Site in Kedungbanteng Sub District in the mid of odd semester. Teachers divide the departure group according to specialty package. To anticipate the explosion of student number, usually the $10^{\text {th }}$ Accounting 1 and 2 graders go first in the $8^{\text {th }}$ week, followed with the $10^{\text {th }}$ Accounting 3 and 4 , and then the $10^{\text {th }}$ Multimedia 1 and 2 graders.

This agenda has proceeded since 2015 on the initiatives of a senior Indonesian History teacher, Drs. Subagyo, aiming to invite the students to build their own knowledge on the material taught, cultural product of preliterate human. Before conducting site learning, teachers explain first the material of preliterate human's cultural product and then play video about excavation process or the process of exploring the fossils existing in Semedo Ancient Site. Then, they are asked to respond to and to analyze the video shown. Then teachers give observation and interview guide.

In the following week, the students are invited to go to Semedo Purbakala Site and given space for observation, in-depth interview, and documentation in the explanation around Ancient Site in Mr. Dakri, the finder of fossil, and Mbak Tanti Asih, as the fossil finder's daughter giving information about fossil finding and site maintenance as well.

From the result of observation and interview with finder and site organizer, the students are invited to climb the mountain where the fossil was found and to observe surrounding condition, perhaps to find another fossil. It is in the trip going along the mountains that contextual learning starts. The students begin to organize the materials delivered by teachers in the class, and to prove it really when they are in Semedo ancient site.

Next, individual students are told to write the report of field study on Semedo Ancient Site and to present experience and lesson obtained from the site learning. Then along with teachers, they draw a conclusion and give constructive recommendation concerning the condition of Semedo ancient site to be conveyed by the teachers to site organizer and to be the material of improvement in the future.

\section{CONCLUSION}

Contextual learning of Semedo Ancient Site is applied effectively in Indonesian History subject. Students study more enthusiastically the Indonesian History; preliterate human's life pattern, and characteristics of fossil coming from middle Pleistocene period, and can distinguish the type of life tools in Mesolithic and Neolithic periods. However, the accessibility is less supporting including damaged and puddling road in rainy season, less complete museum development, and less optimum objective of tourism-conscious group in education area. As a result, many people have not known and understand yet completely the existence of Semedo Ancient Site and its benefit in education area.

\section{REFERENCES}

[1] Nurhadi.2002. Pendekatan Kontekstual (Contextual Teaching and Learning). Jakarta: Depdiknas Dirjen Dikdasmen.

[2] R.K.Yin.2013. Studi Kasus Desain dan Metode. Jakarta: PT Raja Grafindo Persada.

[3] E.P. Widoyoko. 2009. Evaluasi Program Pembelajaran : Panduan Praktis Bagi Pendidik dan Calon Pendidik. Yogyakarta: Pustaka Pelajar.

[4] H. Hasan. 2009. Evaluasi Kurikulum. Bandung : Remaja Rosdakarya. 
[5] S. Arikunto and C. Safrudin. 2009. Evaluasi Program Pendidikan : Pedoman Teoritis Praktis Bagi Mahasiswa dan Praktisi Pendidikan, cetakan ketiga. Jakarta : Bumi Aksara.

[6] I. Q. Muriana 2015. Pemanfaataan Situs Purbakala Semedo sebagai Sumber Belajar Sejarah bagi Siswa SMAN 1 Pangkah dan SMAN 2 Slawi Kabupaten Tegal. (Skrispi: Universitas Negeri Semarang).

[7] Wiyanarti, Erlina. Model Pembelajaran Kontekstual dalam Pengembangan Pembelajaran Sejarah. Online Accessed [14/08/2017]. 